\title{
OJS OPEN

\section{A TOPONÍMIA COMO RECURSO DIDÁTICO NO CONCEITO DE LUGAR NAS AULAS DE GEOGRAFIA DO ENSINO MÉDIO}

\author{
Erielson Miranda Pereira ${ }^{1}$
}

\begin{abstract}
1 Universidade Federal do Rio Grande do Norte - UFRN, E-mail: erielson.pereira1@prof.edu.ma.gov.br, Orcid: https://orcid.org/0000-0003-0504-032X
\end{abstract}

Artigo recebido em 11/09/2021 e aceito em 06/04/2021

\begin{abstract}
RESUMO
O propósito deste artigo é apresentar a estratégia pela qual a toponímia foi utilizada como recurso didático para trabalhar o conceito de lugar nas aulas de Geografia com os alunos do Ensino Médio do Centro de Ensino Anjo da Guarda, localizada no bairro de mesmo nome no Município de São Luís MA no ano de 2020. O lócus investigativo é composto de 53 ruas que constam nos arquivos escolares como endereços particulares dos alunos do Primeiro Ano. Optou-se por explanar sobre a toponímia, conceituando e classificando a partir dos estudos de Dick (1990) para analisar os topônimos catalogados. Em virtude da pandemia, as atividades ocorrerem em formato de ensino remoto. Os alunos foram incentivados e provocados para a aprendizagem na forma síncrona e assíncrona no sentido de estabelecer uma leitura crítica do lugar a partir de uma percepção toponímica possibilitando reconhecer aspectos geográficos e socioeconômicos de sua vivência. Os resultados permitiram validar positiva e interdisciplinarmente o tema, identificando que existe um padrão toponímico entre o ato de nomear os espaços públicos e o contexto histórico em que se atribui os nomes, o tributo a representantes do poder político e seus familiares e elementos religiosos frente a elementos físicos da região como forma de imprimir as relações de poder e posse.
\end{abstract}

Palavras-chave: toponímia; lugar; Geografia; ensino remoto; interdisciplinar.

\section{TOPONYMY AS A TEACHING RESOURCE IN THE CONCEPT OF PLACE IN HIGH SCHOOL GEOGRAPHY CLASSES}

\begin{abstract}
The purpose of this article is to present the strategy by which toponymy was used as a didactic resource to work the concept of place in the Geography classes with the students of the Guardian Angel Teaching Center, located in the neighborhood of the same name in the city of São Luís - MA in the year 2020. The investigative locus is composed of 53 streets that appear in the school files as private addresses of First Year students. It was decided to explain the toponymy, conceptualizing and classifying from the studies of Dick (1990) to analyze the catalogued toponyms. Due to the pandemic, the activities take place in a remote teaching format. Students were encouraged and provoked to learn
\end{abstract}




\section{Revista Ensino de Geografia (Recife) V. 4, No. 3, 2021}

in synchronous and asynchronous form in order to establish a critical reading of the place from a toponymic perception making it possible to recognize geographical and socioeconomic aspects of their experience. The results allowed a positive and interdisciplinary validation of the theme, identifying that there is a toponymic pattern between the act of naming public spaces and the historical context in which the names are attributed, the tribute to representatives of political power and their families and religious elements in front of physical elements of the region as a way of printing the relations of power and possession.

Keywords: toponymy, place, Geography, remote teaching, interdisciplinary.

\section{Introdução}

Ao se estudar o nome dos lugares, pode-se também aprender sobre a realidade do grupo que o habita: aspectos sociais, políticos, culturais e geográficos. É uma oportunidade de utilizar-se do nome de batismo dos espaços públicos para contribuir para as aulas de Geografia do Ensino Médio, especialmente em relação ao estudo do lugar objetivando proporcionar encontros produtivos entre a disciplina, teorias, práticas e, sobretudo, entre pessoas.

Este artigo apresenta os resultados de uma investigação a respeito da nomenclatura dos logradouros públicos onde residem os alunos do Primeiro Ano do Ensino Médio do Centro de Ensino Anjo da Guarda, escola da rede pública estadual localizada no bairro Anjo da Guarda, área urbana do município de São Luís - MA. Para tanto, empreendeuse um estudo sobre os topônimos ${ }^{1}$, ou seja, nomes próprios de lugares, sua origem e evolução. Neste sentido, realizou-se uma investigação a respeito dos logradouros que correspondem ao endereço dos alunos matriculados no Primeiro Ano do Ensino Médio da do Centro de Ensino Anjo da Guarda, escola localizada na cidade de São Luís - MA no bairro que lhe nomeia. O estudo busca afirmar que é possível a partir de uma análise dos topônimos compreender o conceito de lugar, território e identidade regional. $\mathrm{O}$ que os nomes destes lugares reproduzem conforme os registros históricos do povoamento desta região.

Em virtude da falta de trabalhos acerca da discussão e análise dos nomes em um contexto histórico-geográfico torna-se relevante identificar o perfil toponímico da área urbana do município com o objetivo de propor uma aprendizagem significativa da leitura dos espaços geográficos no ensino de Geografia.

No Brasil, tendo em vista a ação de nomear alguns lugares com denominações próprias, houve a necessidade de elevar também a importância do estudo e do

\footnotetext{
${ }^{1}$ Termo de origem grega. Decompondo-se em topos (lugar) + onyma (nome, designação)
} 


\section{Revista Ensino de Geografia (Recife) V. 4, No. 3, 2021}

(re)conhecimento da história nacional por meio do inventário desses nomes através de uma nova ciência, denominada Toponímia².

[...] A Toponímia é uma herança preciosa das culturas passadas. Batizar as costas e as baías das regiões litorâneas sempre foi a primeira tarefa dos descobridores. Um verdadeiro tapete de nomes recobre a terra que se torna assim objeto de estudo. $\mathrm{O}$ batismo do espaço e de todos os pontos importantes não é feito somente para ajudar uns aos outros a se referenciar. Trata-se de uma verdadeira tomada de posse (simbólica ou real) do espaço. (CLAVAL, 2007, p.189).

Toponímia caracteriza-se pela interdisciplinaridade. É considerada uma parte da linguística, com fortes ligações com a Letras, História e Geografia. Na Geografia seus estudos servem para análise e compreensão do conceito de lugar, território e identidade.

Considerando assim, a cidade como produto do processo de construção e expressão humana, a ciência geográfica encontra no estudo toponímico um vasto campo de análise, seja em um recorte temporal atual ou no passado. Para este estudo Abreu (1998, p. 93-94) discorre sobre o assunto, afirmando que

[...] nada impede da Geografia estudar o passado. Não há razão também para que ela se limite à recuperação das formas morfológicas que restaram dele. As análises complexas e abrangentes que a disciplina vem fazendo para compreender o momento atual de globalização podem também ser feitas para os tempos passados, bastando para isso que façamos as necessárias correções metodológicas.

Portanto, o entendimento da Geografia como uma modalidade de análise histórica dos processos formadores da cidade e do território urbano dela constituído é, para Morais (2000), a visão da geografia humana como uma história territorial. Desse modo, o processo nomear lugares é uma forma de refletir acerca das transformações e mutações do território e suas territorialidades na formação das sociedades urbanas.

O território está imerso em relações de dominação e apropriação do espaço geográfico que vai da dominação político-econômica a cultural-simbólica. Cabe aqui, distinguir território e territorialidade para reconhecermos o sentido simbólico para a construção da identidade.

O território envolve sempre relações de poder, econômico-políticos e simbólicoculturais, tem identificação e simbologia de alguém ou um grupo de indivíduos através de referências simbólicas, a exemplo a denominação dos espaços públicos de uma cidade. Assim

\footnotetext{
2 Toponímia estuda o nome dos lugares e designativos geográficos: física, humano, antrópico ou cultural. Para Dick (1990, p. 36) Essa é a ciência que se dedica ao estudo dos nomes de forma genérica, levado em conta o caráter motivacional na formação deles.
} 


\section{Revista Ensino de Geografia (Recife) V. 4, No. 3, 2021}

o território muitas vezes é associado a lógica política, um governo sobre município, ou uma base física, uma fração de espaço geográfico delimitado e apropriado através de critérios políticos, econômicos e culturais. Segundo Haesbaert (1999, p. 185-186),

O território envolve não somente um "ter" mediador de relações de poder (políticoeconômico) sobre parcelas do espaço, ele compõe também o "ser". Ao mesmo tempo prisão e liberdade, lugar e rede, fronteira e coração, o território de identidade pode ser uma prisão que esconde e que oprime ou uma rede que se abre e se conecta a um coração que emana poesia e novos significados.

No processo de construção e apropriação do território criam-se um conjunto de ações colocando-o como uma área procriada e ocupada por determinado grupo social. Essas ações seriam resultado de um lado da aceitação de uns grupos sociais decorrente da existência da diferenciação espacial e de outro lado projetos de reprodução social.

Tomaremos como referência a análise sobre o território de Haesbaert em sua obra "O mito da desterritorialização: do fim dos territórios à multiterritorialidade", de 2004, a respeito das dinâmicas territoriais. A concepção é de uma dimensão espacial que se revela em processos de dominação mais concretos, tanto pela produção material quanto em termos imateriais na produção de identidade e simbolismo com o lugar.

[...] o território, imerso em relações de dominação e/ou de apropriação sociedadeespaço, desdobra-se ao longo de um continuum que vai da dominação políticoeconômica mais "concreta" e "funcional" à apropriação mais subjetiva e/ou “cultural-simbólica” (HAESBAERT, 2004, p. 95-96).

O território, portanto, é a síntese de um instrumento de dominação política e um espaço de identidade cultural e territorialidades. A territorialidade se apresenta com o sentido de pertencimento, uso e vivência em um recorte do espaço. Trata-se de uma dimensão mais estrita, como as pessoas se organizam e dão significado ao lugar. Nesse sentido, a toponímia está estritamente relacionada com as relações de poder.

Posto isso, o ponto de partida foi analisar e catalogar o nome das ruas que constam no endereço dos alunos considerando as contribuições de Dick (1990), autora de referência no que diz respeito aos estudos toponímicos brasileiros, publicações a respeito do estado do Maranhão, São Luís e do bairro onde a escola é localizada - Anjo da Guarda, do ponto de vista qualitativo e quantitativo, analisando os mecanismos de nomeação atentando para as relações entre o número de topônimos, sua classificação e as razões que influenciaram nas denominações desses lugares. 


\section{Revista Ensino de Geografia (Recife) V. 4, No. 3, 2021}

A existência desses dados auxilia na criação da identidade local com o logradouro. Desse modo, são de grande relevância os resultados da pesquisa, uma vez que, ao identificar-se os signos motivadores, suas origens e sua evolução toponímica, resgata-se os valores inseridos na base histórico-social da região estudada.

A relação entre toponímia e poder é muito evidente, nomes em geral estabelecidos por lei, na maioria dos casos sem consulta prévia à população e indicam essa relação de poder ao representar atos impostos pelas autoridades. É uma honra ao ocupante do poder ter o seu nome marcado para além da história do município.

Um dos produtos do processo territorial de batizar os lugares é a construção da identidade associada a grupos familiares que alternam o poder em seu projeto de dominação na política regional e local, estadual e municipal. No Brasil temos traços marcantes que personalizam esta afirmação. No estado da Bahia sobre a oligarquia Magalhães. "São homenagens explícitas ao poder e representados em todas as regiões do estado" (RAMOS, 2008, p. 236). O Rio Grande do Norte, é fortemente marcado pela organização familiar Albuquerque Maranhão ${ }^{3}$ que esteve à frente do poder estadual demarcando uma grande porção do espaço com os nomes de seus membros. Com o passar do tempo outros grupos políticos também trouxeram uma nova dinâmica a toponímia do Rio Grande do Norte com o fortalecimento de outros centros de comando.

O estado do Maranhão, que abriga a área de estudo, sobre a liderança de José Sarney foi marcado pela forte influência desta oligarquia (sarneísmo) com direta condução no ato de nomear municípios, obras de infraestrutura e monumentos públicos ${ }^{4}$.

Ainda com relação ao Maranhão, hoje as oligarquias locais são sustentadas numa relação baseada na centralização de recursos políticos e financeiros intermediadas por ela. São oligarquias que alternam o poder local e regional e atendem a interesses econômicos e particulares do Estado. Também são reconhecidas pelos seus impérios empresariais.

Vieira Filho (1971) e Melo (1990) já descreviam sobre o processo toponímico de São Luís, chegando a discutir a toponímia que os batiza até a data de publicação de seus

\footnotetext{
${ }^{3}$ Ao que se foi possível apurar por meio da historiografia potiguar, coube ao fundador do Partido Republicano, Pedro Velho de Albuquerque Maranhão inaugurar o sistema oligárquico no Estado onde a base econômica dessa primeira oligarquia, foi o açúcar.

4 Após ser eleito governador do Maranhão em 1965, José Sarney inicia um período chamado na literatura política local de sarneysísmo, no qual uma família deteve as mais privilegiadas posições de poder. Hoje o estado conta com cidade, Presidente José Sarney, obras e bens públicos e 161 escolas espalhadas pelo estado que expressam em seu batismo o culto à família Sarney.
} 


\section{Revista Ensino de Geografia (Recife) V. 4, No. 3, 2021}

textos. A denominação dos municípios e distritos só foi regulamentada em lei ${ }^{5}$ no Estado do Maranhão a partir do ano de 1975 a princípio em São Luís.

Os municípios representam o poder político local a nível de Estado. Ao longo da criação dos territórios houve embates e acordos políticos que resultaram em manifestações de poder através do ato de nomear os espaços públicos. Pode-se inferir que a toponímia nem sempre refletiu a identidade regional e as manifestações culturais da população local, questões de natureza física ou econômicas, mas sim, a vontade política de poderosos locais.

A identidade é analisada em diversas áreas de conhecimento, a citar: Psicologia, História, Sociologia, Geografia etc. Relacionada tanto a individualidade quanto a coletividade existe um consenso de que a identidade é uma construção social. A identidade regional é construída ao longo da história, são elaboradas e reforçadas através de um território, ou seja, um espaço delimitado e dominado (simbolicamente pela toponímia) e está ligada ao lugar onde se vive.

“A identidade regional já é fixa, natural e imutável” (SOUSA, 2016, p. 97). Quando nos referimos a identidade regional não se remete só a questões geográficas de dimensão espacial, administrativa, fiscais etc. A interpretação de identidade regional vai além desta divisão geográfica e econômica. As relações que se estabelecem neste território são resultados de uma homogeneização de relações sociais, hábitos e cultura presentes no cotidiano. Acontece dessa forma um mesmo discurso identitário que revelam a identidade regional.

Referente ao processo de identificação regional, para Castro (1992, p. 33) a percepção é,

[...] A região é então uma fração estruturada do território. Por constituir uma estrutura, a região possui uma identidade que permite diferenciá-la do seu entorno. Essa personalidade regional possibilita sua delimitação a partir da compreensão de especificidades que ela contém. A região é, portanto, concreta, observável e delimitável. Como qualquer segmento do espaço, a região é dinâmica, historicamente construída e interage com o todo social e territorial.

Esse é o caso do município de São Luís, e de tantos outros que compõem o estado, cuja característica principal é a forte particularidade através das características físicas, econômicas e culturais e históricas e de como foram moldadas as biografias dos seus

\footnotetext{
5 A Lei n. 2.151, de 04 de fevereiro de 1975, que, entre outras providências, estabelecia as nornas para a nomeação de bairros, vilas povoados e logradouros públicos. A lei deixa clara que se trata para a nomenclatura local e não estadual.
} 


\section{Revista Ensino de Geografia (Recife) V. 4, No. 3, 2021}

moradores. São personagens que ao longo da evolução do lugar acabam por deixar registros travados nos nomes dos comércios, ruas, praças e monumentos públicos.

O lugar desempenha um importante papel na compreensão de fenômenos sociais e do espaço geográfico "quando o espaço nos é inteiramente familiar, torna-se lugar" (TUAN, 1983, p.83). Portanto, promover nas aulas de Geografia o encontro do conhecimento científico com o cotidiano dos alunos através do estudo dos topônimos é uma boa metodologia para captar conceitos geográficos e pode constituir como um elemento chave na introdução de trabalhos de campo e em um diálogo recíproco na sala de aula.

Os nomes dos logradouros no Brasil estão em íntima relação com o cotidiano dos moradores que vivem (ou viveram) no lugar ou em seu entorno. Os topônimos nascem a partir da fala dos sujeitos e a incorporação deles no cotidiano do grupo advém, quase sempre, de referências presentes na paisagem do lugar. Embora o topônimo esteja relacionado a uma forma de comunicação, a sua função não é de significar, mas de identificar os lugares. "Serve de menção ao domínio cartográfico do homem”. As referências na paisagem podem ser representadas por alguém muito popular no local, por um empreendimento comercial ou igreja consagrado a algum santo, por um acidente geográfico ou, ainda, por elementos da natureza característicos da localidade.

Este artigo representa o resultado do mapeamento dos logradouros referente ao endereço particular dos alunos afim de contribuir para a construção do conhecimento geográfico, histórico e turístico. Muitos nomes de ruas, de bairros ou até mesmo o nome do município, explicam como estes surgiram e quais foram as personagens importantes da região, além de revelar a influência política e econômica de famílias, pessoas que personificam a cidade e seus moradores. Por meio dos nomes dos logradouros pode-se rememorar fatos históricos e culturais que marcaram a vida de toda uma população além de permitir a conservação do patrimônio toponomástico.

A possibilidade de retirar inferências geográficas e sociais a partir da distribuição dos topônimos deve ancorar-se numa certeza histórica e contextualizar-se nos restantes fenômenos que dão corpo e originalidade a uma região. A pura fixação do texto, pelo menos no ponto de vista da expressão, permite o mapeamento do espaço a estudar, determinando as relações inteligíveis como o enquadramento sociocultural do bairro estabelecendo relações de sentido e significados entre termos e conceitos.

Constituem problemas graves a variação ou indefinição das localidades, designações transitórias, inexistência de placas etc. Quer para a entrega de correspondências, quer para a localização de moradas para quaisquer outros fins, é condição indispensável ter 


\section{Revista Ensino de Geografia (Recife) V. 4, No. 3, 2021}

designações toponímicas de referência estruturada, simples de entender, uniforme e estável no tempo.

Trabalhos como esse poderão gerar frutos semelhantes ao permitir a implantação da toponímia como estratégia para o estudo de lugar, identidade e território no ensino da Geografia. Além disso, esta reserva o conhecimento e o debate da história e da cultura que existe atrás dos nomes de diversas regiões e lugares.

\section{O estudo toponímico}

Estudar a toponímia implica na identificação de características físico-naturais, aspectos socioculturais e econômicos, fatos históricos, fatores que façam refletir sobre a memória. Portanto cada grupo social possui características próprias que são refletidas no processo de nomeação dos lugares onde habitam coletivamente sendo "uma verdadeira tomada de posse (simbólica ou real) do espaço" (CLAVAL, 2007, p.189).

A maior representante dos estudos relacionados a toponímia e antroponímia ${ }^{6}$ no Brasil é a professora e pesquisadora Maria Vicentina de Paula do Amaral Dick ${ }^{7}$, cujos estudos estão voltados para a discussão da Língua Portuguesa no curso de Letras na Universidade de São Paulo - USP.

No âmbito nacional, observamos em pesquisas já desenvolvidas na área da Toponímia, que, atualmente, não se pode assegurar um procedimento fixo ou um modelo sistêmico na seleção, coleta, análise e compreensão das pesquisas escolhidas. Muito dependerá do pesquisador e dos objetivos da pesquisa. Porém, observada a forte identidade cultural e influência política na região, alguns cuidados foram observados, a citar: nomenclatura do qual surgiu a expressão (físico ou antropocultural), cuidados com os regionalismos, procedência histórica e cronológica dos nomes, consonância com os conteúdos geográficos e os agentes políticos-culturais que influenciaram a designação do topônimo.

Portanto, a pesquisa toponímica não se apresenta somente como um conjunto de coleta, classificação e interpretação de nomes próprios de objetos e lugares, para posterior comprovação de acordos socioculturais, mas também informações que proporcionam uma compreensão mais ampla sobre como estas denominações foram aplicadas e conservadas em consonância com os membros da sociedade envolvidos.

\footnotetext{
${ }^{6}$ Antroponímia (do grego anthropos "homem" e onoma "nome"). Pela própria etimologia, evidencia-se que cabe ao estudo dos nomes próprios de pessoa.

${ }^{7}$ No âmbito nacional Dick apresenta as principais contribuições aos estudos toponímicos, traçando um panorama das diversas influências toponímicas brasileiras.
} 


\section{Revista Ensino de Geografia (Recife) V. 4, No. 3, 2021}

O levantamento do processo de identidade das ruas do Estado do Maranhão é um desafio que vem se perpetuando ao longo dos anos. As informações e estudos na área em questão possuem produtos de qualidade à disposição do leitor, principalmente no que se refere à capital. Podemos citar o além da Lei $n^{\circ} 2.151$, encontramos os trabalhos de Vieira Filho (1971) e de Melo (1990), que tratam da nomenclatura local ou a microtoponímia de São Luís. Quanto ao Estado a pesquisa de Dick (1995) e Castro (2017) apresentam um estudo da nomenclatura estadual ou macrotoponímia.

Vieira Filho (1971) e Melo (1990) fizeram um detalhado levantamento da microtoponímia do Centro Histórico de São Luís. Esses pesquisadores, cada um em seu tempo, apresentam um índice toponímico com os diversos nomes já dados às ruas, praças, becos, fontes, largos, portos, travessas, avenidas, parques, lagos, rampas e ladeiras da cidade. Estudos mais recentes têm enriquecido o debate toponímico do Estado, são eles Curvelo (2014) e Castro (2017), a primeira propõe um estudo dos atuais 81 nomes de bairros da capital e a outra atém-se a nomenclatura dos nomes dos municípios do estado.

Estes autores argumentam contra o desconhecimento da população acerca dos personagens que emprestavam seus nomes para compor a nomenclatura das ruas. Propunham o estudo dos nomes das ruas como forma de conhecer a história, geografia e cartografia do lugar, despertando por meio da toponímia uma relação entre o lugar social do indivíduo e a compreensão acerca da nomenclatura deste

[...] Compreender a motivação denominadora, bem como contextualizar a região pesquisada com dados locais da história, geografia e cartografia, é uma necessidade (inter)disciplinar desses estudos, pois torna possível uma melhor interpretação dos dados linguísticos que muitas vezes não estão evidentes na etimologia do nome, ou embora estando, essa contextualização permite inferir informações mais fidedignas a respeito da história dos nomes dos lugares. (CASTRO, 2017, p. 119-120)

No âmbito local os estudos em torno dos topônimos podem ser retirados, sobretudo de produções acadêmicas e literárias que contribuem para os registros históricos do bairro do Anjo da Guarda. Entre os aspectos urbanos que contemplam o bairro podemos citar a monografia Modernização e urbanização no contexto de São Luís na década de 60: o caso do Anjo da Guarda. Conceição (2007). Quanto ao referencial histórico, a bairro é contemplada pela obra do jornalista e escritor Herbert de Jesus Santos (2012), Um Terço de Memória, Entre Anjo da Guarda e Capela de Onça, e os Heróis do Boi de Ouro (A História de Fato e de Direito do Bairro Anjo da Guarda). 


\section{Revista Ensino de Geografia (Recife) V. 4, No. 3, 2021}

$\mathrm{Na}$ mesma linha de raciocínio, foi considerado outro estudo sobre topônimos produzidos por iniciativa do poder público que retrata aspectos geográficos, históricos, políticos, socioculturais, econômicos etc. A principal iniciativa surgiu a partir da aprovação do Plano Diretor, aprovado em 2006, no qual estabeleceu a revisão e atualização da toponímia de São Luís ${ }^{8}$. Em linhas gerais, estas pesquisas podem ser entendidas como uma reação ao crescente interesse e necessidade de preservação da identidade, história, etimologia do nome e um olhar geográfico sobre a toponímia. Sendo possível a incorporação nos processos educativos com a finalidade de inovar o ensino.

As obras estão entre as que comtemplam os referenciais para a pesquisa, possuem uma análise desde a povoação inicial dos arruamentos, lugares, povoados e aspectos geográficos necessários aos resultados pretendidos com a proposta de ensino. Visto que o desconhecimento do próprio espaço de vivência relacionado com a falta de reflexão em uma das formas básicas de interação social - a rua onde mora - torna possível estabelecer uma relação entre o ato de nomear e o discurso.

\section{Geografia e ensino: a compreensão do conceito de lugar sobre o olhar toponímico}

No ensino de Geografia é fundamental que os alunos compreendam o mundo atual, marcado por uma complexa rede de relações econômicas, sociais e culturais, que são ao mesmo tempo, globais e locais.

Neste sentido a compreensão dos seus conceitos-chaves são essenciais para que o aluno possa realizar uma efetiva transposição do senso comum para os conhecimentos científicos. Ensinar sobre o espaço geográfico, paisagem, território, lugar e região implicam em metodologias que proporcionem aos alunos utilizar o conhecimento geográfico para compreender o mundo em que vivem e que possam efetivamente contribuir para que outra realidade seja construída.

Em Geografia uma das discussões mais significativas na literatura geográfica é o estudo do lugar. Entendemos que na Geografia a pesquisa toponímica deve ser coordenada com este conceito visto que o nome dos lugares incorpora vestígios de identidade e atende de alguma forma a interesse material ou simbólico

\footnotetext{
${ }^{8}$ Para a revisão da Lei de Toponímia foi criada a Comissão Toponímica de São Luís, criada pelo Decreto $\mathrm{n}^{\circ}$ 33.607 de fevereiro de 2008, com a finalidade de estudar a toponímia e a origem dos logradouros públicos. Responsável também pela elaboração da minuta de Projeto de Lei e a publicação do Guia Toponímico.
} 


\section{Revista Ensino de Geografia (Recife) V. 4, No. 3, 2021}

No nosso entender, lugar torna-se, então, categoria central, pois trata-se da extensão/apreensão da relação (motivações) que são estabelecidas entre o homem e o próprio nome de lugar: é a sua gênese. Por isso, é essencial, a priori, conceituar lugar em uma dimensão de categoria analítica: motivacional, histórica, linguística, ideológica, social, identitária. (ANDRADE, 2017, p. 593).

A interpretação de lugar sempre esteve presente no debate geográfico, visto ser um espaço fundamental de ocupação da vida humana. A compreensão de ser-no-mundo propõe no presente um debate que envolva um contexto geográfico e social visto as transformações em curso e os novos âmbitos emergentes na localidade.

A noção de lugar evoluiu e se transformou frente as necessidades impostas pelo mundo. A Geografia definida como ciência dos lugares e não dos homens (LA BLACHE, 1914), traz a ideia de lugar associada à de localização de um fenômeno na superfície terrestre. À medida que se acentuaram as crescentes transformações no mundo o lugar passa a ser visto como parte de uma totalidade vinculado a um caráter social e histórico do espaço geográfico global.

No processo de construção do conceito de lugar, o mesmo nunca deve ser visto isolado ou independente. Em seu entendimento faz-se necessário dialogar com motivos externos e internos. "Cada lugar é, ao mesmo tempo, objeto de uma razão global e de uma razão local, convivendo dialeticamente" (SANTOS, 1996, p. 273), ele é fundamental, pois a nível do local ele traz em si a questão de identidade e pertencimento. Compreender o lugar em que vive é compreender a história e conseguir entender o que ali acontece.

Não existem lugares iguais, por mais que tenham infraestruturas semelhantes. Os lugares são formados historicamente por suas características naturais e pessoas que neles se relacionam, por suas ações, construções, seus costumes, sua cultura. A maneira como ocorrem as combinações entre os elementos da natureza e a organização da vida social é que transforma cada local em um lugar único.

O lugar é o cotidiano de cada indivíduo, de cada grupo social, de cada agente do espaço. Para Milton Santos o lugar não está restrito à dimensão cultural ou simbólica do espaço, ou seja, não é apenas uma relação social imaterial. O lugar é simultaneamente uma materialidade e uma imaterialidade; é vivido e percebido; é a dimensão espacial do cotidiano (SANTOS, 1996).

Correspondente à porção do espaço vivido, onde as pessoas estabelecem suas relações mais diretas, sobretudo afetivas. Os lugares, apesar de terem características mundiais manifestas, também são únicos, carregados de características próprias que os diferem dos 
demais lugares, com aspectos físicos, sociais econômicos e políticos. Esta porção do espaço é entendida como:

[...] apropriado para a vida - apropriada através do corpo - dos sentidos - dos passos de seus moradores, é o bairro, é a praça, é a rua, e nesse sentido poderíamos afirmar que não seria jamais a metrópole ou mesmo a cidade latu sensu a menos que seja a pequena vila ou cidade - vivida/conhecida/reconhecida em todos os seus cantos. (CARLOS, 2007, p. 17)

O estudo do lugar exige identificação e, aprender a conhecer sobre o bairro exige a nomeação de ruas, esquinas e outras referenciais arquitetônicas. Conforme Tuan (1983, p. 12) “os lugares são centros os quais atribuímos valor”. O mesmo autor evidencia ainda que os lugares podem ser totalmente apreendidos através de uma experiência total englobando relações íntimas, o lugar como experiência direta, próprias (insider) de quem vivencia. Percebido com todos os sentidos, através dos olhos ao explorar o campo visual (visão), da fragrância transportada pelo vento (olfato), do gosto com respeito as comidas típicas (paladar), a textura das formas da cidade (tato) e o som das ruas (audição). Outros lugares podem faltar o peso da realidade porque o conhecemos apenas de fora - através dos olhos de turistas, pesquisadores e da leitura de um mapa pela internet. É o lugar como experiência indireta, analisado e compreendido através de relações externas (outsider) Tuan (1983). O lugar atinge uma realidade concreta quando nossa experiência com ele é total

\begin{abstract}
Quanto demora para se conhecer um lugar?, o homem moderno se movimenta tanto, que não tem tempo de criar raízes; sua experiência e apreciação do lugar é superficial. Sentir o lugar leva mais tempo. É uma mistura singular de vistas, sons e cheiros, uma harmonia ímpar de ritmos naturais e artificias, como a hora do sol nascer e se por, de trabalhar e brincar. Conhecer um lugar, nos sentidos citados anteriormente, certamente leva tempo. Com o tempo nos familiarizamos com o lugar, o que quer dizer que cada vez mais o consideramos conhecido. (TUAN, 1983, p. 203)
\end{abstract}

A denominação dos lugares revela uma apropriação simbólica, "nomear os lugares é impregná-los de cultura e de poder" (CLAVAL, 2007, p.200). Isso torna a toponímia indispensável para o estudo de grupos que se impõem e se reconhecem nos lugares onde costuma frequentar e viver. O batismo dos lugares demonstra uma relação de poder e ocupação do território. Para falar de um lugar ou de um ambiente faz-se necessário recorrer ao batismo como forma de qualificar os diferentes espaços. A esse respeito,

As sociedades sedentárias e organizadas têm necessidade de uma toponímia fixa. As relações complexas só são possíveis quando os indivíduos ou os grupos podem ser localizados e os caminhos são guiados por referenciais bem visíveis na paisagem. $\mathrm{O}$ poder apropria-se das terras fazendo constar nos registros, planos ou mapas as coleções de nomes de lugares. (CLAVAL, 2007, p.201) 
Ao propor o estudo dos topônimos do município como possibilidade de os alunos se apropriarem das histórias da sua própria vida, conduz a um processo de construção do espaço que lhe é imediato, próximo e possível de observar concretamente.

Estudar e compreender o lugar é fundamental para tornar o estudo da Geografia significativo, visto o processo de reconhecer os vínculos afetivos que ligam as pessoas aos lugares. A Geografia escolar, aquela que se ensina e se aprende na escola, potencializa e amplia a leitura do lugar em que o aluno vive. Há várias possiblidades de estudar o lugar: livros didáticos, vídeos, fotografias, notícias vinculadas na internet, mapas, roteiros etc. Segundo Callai (2000, p. 125-126),

\begin{abstract}
Vários são os lugares possíveis de se estudar. O importante é que sejam lugares significativos para a vida dos alunos. Poder-se-ia falar em espaços do cotidiano. No cotidiano das nossas vidas, expressam-se as regras gerais do mundo globalizado. [...] Lugares do cotidiano de nossas vidas funcionam como laboratórios para compreender o mundo e as diferentes formas de vida do homem.
\end{abstract}

É importante que os alunos tenham condições de identificar as particularidades do lugar em que vivem, assim como as diferentes relações que esse lugar estabelece em outros lugares do planeta. Com base na realidade do lugar nas quais as aprendizagens são situadas se faz necessário segundo a $\operatorname{BNCC}(2018$, p.16) trabalhar ações que permitem "contextualizar os conteúdos dos componentes curriculares, identificando estratégias para apresentá-los, representá-los, exemplificá-los, conectá-los e torná-los significativos”.

De acordo com a BNCC, A Geografia tem um importante papel em desenvolver o pensamento espacial dos alunos ao estimular o seu raciocínio geográfico, tanto para representar quanto para interpretar os constantes movimentos de transformação do espaço geográfico. No entanto para que isso aconteça, é fundamental que os alunos apropriem de conceitos geográficos que certamente os auxiliarão a interpretar a realidade em que vivem.

Nessa direção, a BNCC está organizada com base nos principais conceitos da Geografia contemporânea, diferentes por níveis de complexidade. Embora o espaço seja o conceito mais amplo e complexo da Geografia, é necessário que os alunos dominem outros conceitos mais operacionais e que expressam aspectos diferentes do espaço geográfico. (BNCC, 2018, p. 361)

No processo de ensino da Geografia é necessário promover situações por meio das quais os alunos possam refletir a respeito das relações sociais, culturais, econômicas e 


\section{Revista Ensino de Geografia (Recife) V. 4, No. 3, 2021}

naturais em conjunto, reconhecendo tanto suas particularidades em escala local, a exemplo o espaço vivido por eles, quanto as características dessas relações em escala global.

Portanto o lugar, enquanto espaço percebido e que possui significados efetivos é o conceito que permite utilizar da realidade vivenciada com o contexto toponímico construído ao longo da rede urbana do município em estudo.

\section{Considerações sobre a localização da área de estudo}

Nesta análise cabe esclarecer o que vem a ser município, pois a sede deste é sempre uma cidade, esta capaz de exercer influências diversas, destacando as econômicas e políticas. Nesse contexto, cabe a interpretação de Pinto (2003, p.29) para a compreensão entre município e cidade:

O município é a menor unidade territorial brasileira com governo próprio, é formado pelo distrito-sede, onde acha-se localizada a cidade, que é a sede municipal e que leva o mesmo nome do município e, que corresponde à zona urbana municipal e; também, pelo território ao seu entorno, a zona rural municipal, que pode ser dividida em distritos, cuja maior povoação recebe, geralmente, o nome de vila.

O surgimento do município de São Luís está relacionado ao período de dominação expansão das potências europeias. Com os franceses após fracassada tentativa de estabelecerse no Rio de Janeiro trouxe para a então capital maranhense a instalação da França Equinocial, em 1612 - ano de fundação da cidade. A partir de então surgem as disputas com Portugal pelo território já dividido pelo tratado de Tordesilhas. Expulsos três anos depois em 1615 sob o comando de Jerônimo de Albuquerque teve início o processo de ocupação efetiva e colonização do território pelos portugueses a partir do núcleo urbano hoje denominada Centro Histórico. São Luís também esteve sob o controle holandês no período de 1641 a 1644.

\footnotetext{
Em pouco tempo construíram várias cabanas (...) de um e dois andares, e mais um grande armazém para o qual transportaram, eles próprios, toda a carga de nossos navios. E com auxílio dos franceses acharam jeito de montar no forte, embora fosse muito alto, vinte canhões grandes para a defesa.

Junto ao forte há uma grande praça, tão cômoda quão admirável. Nela se encontram belas fontes e regatos, que são a alma de uma cidade, existindo também todas as comodidades desejadas, como serem paus, pedras, barro e outros materiais que tornam a construção barata. (D'ABBEVILLE, 1975, p.58).
}

O período que seguiu após o início da colonização foi marcado pelo deslocamento para o interior da ilha e do continente. No século XVIII e XIX o que se viu foi o avanço do sistema agroexportador enriquecido pela mão de obra escrava e o cultivo do algodão. $\mathrm{O}$ 
Maranhão atravessou uma época de estabilidade e crescimento econômico. É nesse momento que a vida cultural em São Luís ganha expressividade o que levou a cidade a receber o título de Atenas Brasileira.

[...] Até a década do século XVIII a área urbana se projeta, a partir do núcleo inicial localizado próximo ao Forte e ao Cais, em direção ao Largo do Carmo. A seguir o povoamento se dá no sentido Carmo-Desterro, atraídos pelo Convento das Mercês e pela Fonte das Pedras. Mais tarde, a ocupação se orienta para o bairro do Egito, Rua do Ribeirão e cercanias da Igreja de Nossa Senhora do Rosário dos Pretos (...) Já no final do século, o povoamento se expande em diversas direções: ganha o rumo do Convento de Santo Antônio e Remédios e também o da Igreja de São Pantaleão e outras áreas já razoavelmente afastadas da que abrigava os primeiros prédios[...]. (MOTA; MANTOVANI, 1988, p.21).

A passagem do modelo imperial para o modelo republicano entre os séculos XIX e XX marcou grandes transformações na estrutura maranhense, a citar: o estado laico, abolição da escravidão, descentralização política e registro civil. São Luís não suportou a ascensão econômica de outros centros urbanos e teve um declínio visto a decadência da sua economia agroexportadora de mão de obra escrava agora abolida o que acarretou no empobrecimento de grande parte da população. Nesse período a população deslocou-se do Centro antigo para um novo bairro, o Monte Castelo e outros bairros operários foram surgindo esvaziando o centro e desvalorizando os imóveis da região histórica da cidade passando a ser ocupada pala população mais pobre.

Figura 1: Município de São Luís - MA

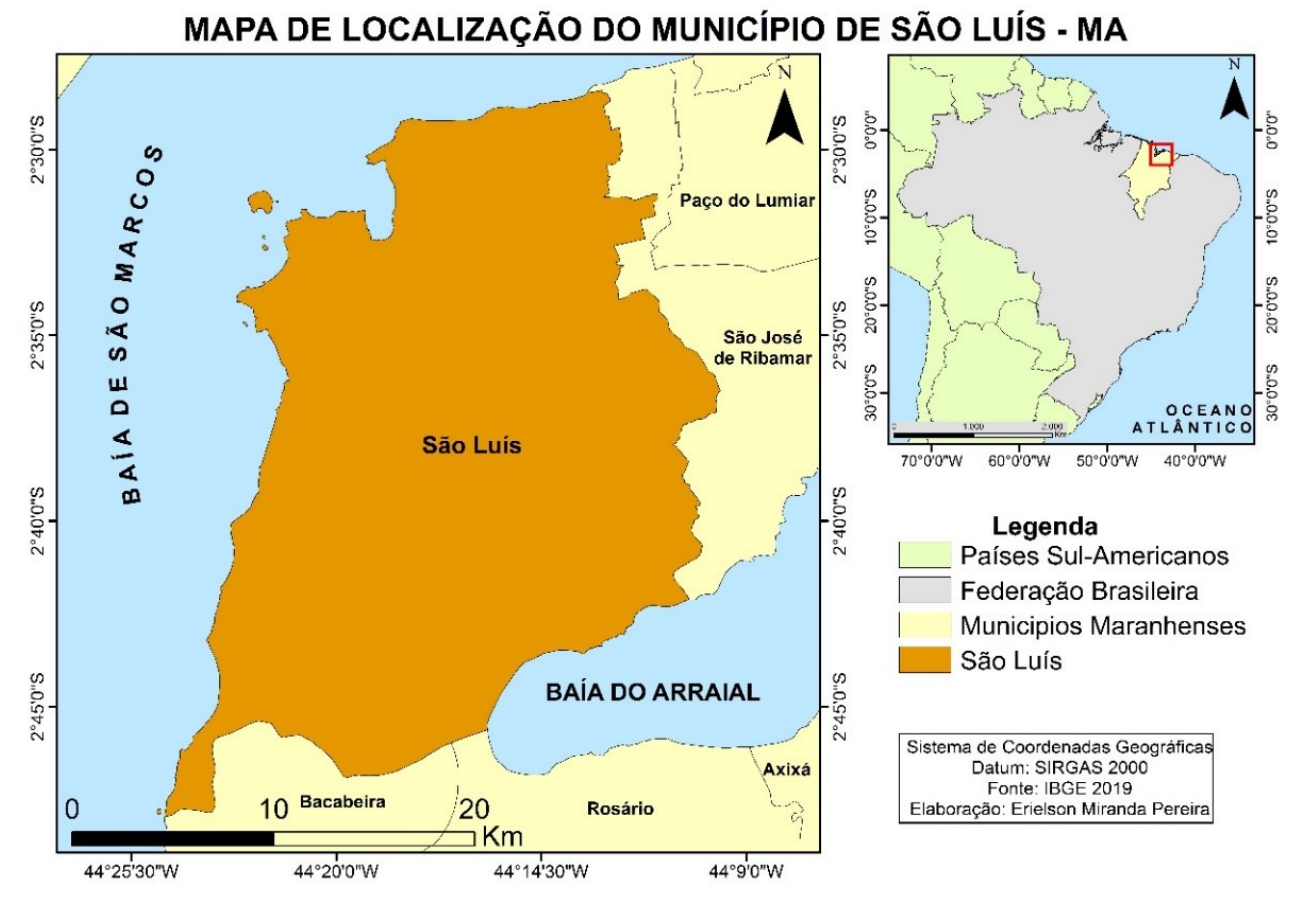




\section{Revista Ensino de Geografia (Recife) V. 4, No. 3, 2021}

Fonte: Elaborado pelo autor, 2020

No século XX a situação econômica do estado do Maranhão não era diferente de outros estados distantes do centro do poder ancorado na economia cafeeira entre São Paulo e Minas Gerais. Mudança significativa só ocorreria com a ascensão de Getúlio Vargas ao poder a partir da Revolução de 30 que trouxe para o Maranhão um personagem político, o pernambucano Vitorino Freire que instaurou um novo período oligárquico denominado vitorinismo (BUZZAR, 1998) até a década de 60 quando assume o poder do estado José Sarney implantando até o século XXI um novo período oligárquico, o sarneísmo (GUILHON, 2007).

A partir da metade do século XX, em virtude de investimentos regionais, o Estado passou por muitas intervenções urbanas, obras de infraestrutura e grandes projetos industriais como a Companhia Vale do Rio Doce (atual VALE) e Alumar. Soma-se a este processo a construção de rodovias e estradas de ferro conectando o interior a capital maranhense favorecendo a migração rumo a cidade e como resultado o forte crescimento populacional, elevação do número de ocupações habitacionais e surgimento de novos bairros, estes com visíveis problemas de ocupação irregular e infraestrutura até o período atual.

Além destes projetos de nível estadual era crescente a preocupação para a questão de moradia da capital. O governo via a necessidade da remoção de grande parte de moradias pobres da região central de São Luís, principalmente dos bairros mais pobres, Goiabal e Madre Deus, próximos ao Rio Bacanga. Assim previa-se a construção do aterro do Bacanga conectando a cidade a outro grande empreendimento, o Porto do Itaqui.

Um incêndio de grandes proporções atingiu os casebres dos bairros da Madre Deus e Goiabal na noite do dia 14 de outubro de 1968. Os moradores, agora desabrigados, precisavam ser alocados e surgiu a proposta de alojar na região do Itaqui. Assim com o incentivo do governo e a necessidade das vítimas do incêndio aparece o bairro Anjo da Guarda onde iriam se localizar na região o campus da Universidade Federal do Maranhão UFMA e o novo Porto do Itaqui. Antes do incêndio o as diretrizes já estavam direcionadas ao sul da cidade: obras da estrada de acesso ao novo porto e a Universidade.

[...] o governo do estado buscou ocupar regiões distintas da capital do estado a fim de promover o tão sonhado crescimento capitalista, ainda que de forma subalterna e brutalmente autoritária, sobretudo para as vítimas do desastre de 14 de outubro de 1968. De acordo com as previsões, conjuntos habitacionais, edifícios empresariais e até o distrito industrial teriam lugar nas cercanias do novo porto; e, evidentemente, o centro da cidade, o palco do progresso passaria por uma renovação com as novas vias e o aterro do rio Bacanga. Poucas semanas após o incêndio, um grande contingente de desabrigados deveriam ser rapidamente instalados na região do Itaqui, no futuro bairro do Anjo da Guarda. (COSTA, 2018, p. 8-9) 
Na continuidade dos grandes projetos surge o Projeto Grande Carajás, inserido numa política de exportação de minérios e aplicado no início dos anos 80 do século passado executado pela então estatal Vale do Rio Doce. Localizado no entorno do Porto do Itaqui e bairro do Anjo da Guarda, este sofreou um forte processo de crescimento, marcado pela falta de ordenamento espacial por parte do poder público.

Até o início da década de 1970, as ocupações concentravam-se nas proximidades dos rios Anil e Bacanga, não se estendendo muito além dos arredores do centro. Posteriormente, outras localidades passaram a ser palco desse processo, formando áreas com ampla concentração de população carente, como é o caso do ItaquiBacanga, assim conhecido após a inauguração oficial do Porto do Itaqui em 1971. (COSTA, 2008, p. 7)

A identidade regional como o bairro é marcante e ultrapassa a espacialidade do recorte regional que o corresponde. A comunidade do Anjo da Guarda teve sua realidade alterada pelos grandes projetos das décadas de 1960, 70 e 80, que marcou sua resistência pelos movimentos sociais e pelo desenvolvimento da cultura popular. A combinação da forte religiosidade dos moradores com a luta pela conquista dos direitos serviu de inspiração para a fundação em julho de 1975 do Grupo Independente de Teatro Amador - GRITA que vem promovendo desde então atividades artístico-culturais com participação direta da comunidade. O grupo montou o espetáculo Via Sacra em 1981, com o propósito de traduzir o sentimento libertário da Paixão de Cristo na movimentação em torno do desenvolvimento da própria comunidade ilustrada em peças ao ar livre e desde então o espetáculo é montado na Semana Santa. Isso indica uma qualificação, apropriação e construção das representações que o denomina. Observamos no topônimo que "batiza" o bairro é advindo de uma valorização da importância do nome no sentido imaginário, cartográfico e identitário do lugar.

\footnotetext{
Anjo da Guarda era um sítio onde hoje é chamado de Residencial Ana Jansen, lá era o Sítio Anjo da Guarda. Inclusive, o nome desse sítio está no livro O Mulado, de Aluísio Azevedo. Como esse nome já era conhecido, depois da fundação do bairro, eles colocaram o nome de Vila Anjo da Guarda, mas antes de ser Anjo da Guarda, onde o bairro iniciou, era chamado de Conjunto de Telha e antes, também disso, esta localidade aqui que eram vários sítios, era chamada de Itapicuraíba, pedra miúda de igarapé pequeno, o nome do teatro daqui da comunidade. Depois de Vila Anjo da Guarda, mudou para o bairro Anjo da Guarda. Aqui era zona rural, depois se transformou e hoje está no perímetro urbano. (CURVELO, 2014, p.311)
}

O bairro abriga o Centro de Ensino Anjo da Guarda - CEAG (figura 2), local de intervenção da pesquisa proposta pelo pesquisador/professor titular de Geografia das turmas desta escola. A escola é uma das que se confundem com a história do bairro, fundada em 
1983, o antigo Centro de Ensino de Segundo Grau - CESG, atual CEAG, funcionou desde seus primeiros anos como escola de segundo grau da rede pública do estado e hoje homenageia no topônimo o bairro que a nomeia. A possibilidade de acesso as fontes e documentos públicos permitiram analisar as designações dos topônimos, a caracterização da estrutura urbana concentrada na região de entorno da escola e a possibilidade de discutir os processos de nomeação e relações de identidade entre as particularidades dentro dos topônimos identificados na pesquisa.

Figura 2: Localização da área de estudo

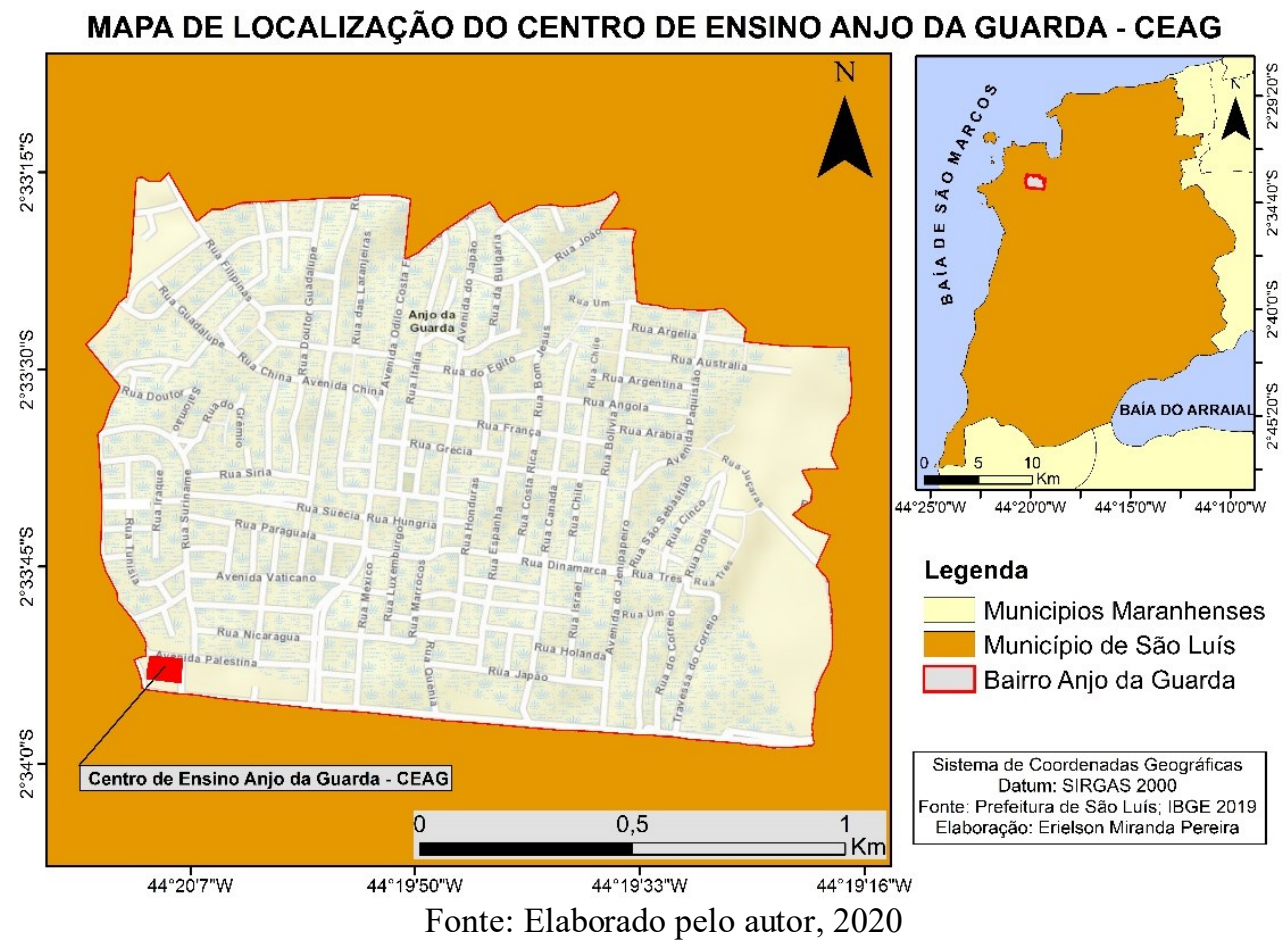

Devemos registrar que segundo a Prefeitura de São Luís (2017), a qual reúne as informações sociais e de infraestrutura municipal por regiões definidas pelo Cadastro Técnico da Secretaria Municipal de Urbanismo e Habitação - SEMURH como Unidades Fiscais e reconhecidas convencionalmente por Bairros, cujos limites foram agrupados em Distritos Urbanos, o bairro onde é localizado a escola pertence ao Distrito Urbano do Anjo da Guarda (Figura 2). O Distrito Urbano é composto por bairros que exercem forte influência socioeconômica sobre os demais do seu entorno tendo as suas particularidades dentro da área urbana do município de São Luís ${ }^{9}$ com determinantes socioeconômicos, políticos e culturais

9 Essas divisões e nomenclaturas - Distrituo Urbano e Bairro - foram estabelecidas de acordo com a Prefeitura Municipal de São Luís - Instituto da Cidade, Pesquisa e Planejamento Urbano e Rural - INCID Através da 


\section{Revista Ensino de Geografia (Recife) V. 4, No. 3, 2021}

desde sua formação territorial a consolidação no centro urbano da capital. O Distrito Urbano do Anjo da Guarda é composto pelos bairros do Anjo da Guarda, Fumacê, Gancharia, Vila Bacanga, Vila Dom Luís e Vila Isabel.

\section{Descrição metodológica do estudo desenvolvido em formato remoto}

O lócus investigativo constitui-se das ruas que constam nos arquivos da escola, como endereço das residências dos alunos matriculados no Primeiro Ano do Centro de Ensino Anjo da Guarda - CEAG localizado no Bairro Anjo da Guarda em São Luís - MA. Um dos locais de vivência dos alunos daquela escola da rede pública estadual. Para apoiar o estudo quanto ao entendimento teórico do tema toponímia e sua relevância na compreensão sociolinguística de um determinado espaço utilizou-se a metodologia de Dick $(1986,1990)$.

Como já referido, topônimo é o nome de um lugar, um nome geográfico, um identificador de posição, um ponto de referência, um histórico de uma sociedade, um legado de uma nação para tradição oral. Nesse contexto, a pesquisadora traz o papel humano em meio ao processo de nomeação de lugar

\footnotetext{
Verdadeiros testemunhos históricos de fatos e ocorrências registradas nos mais diversos momentos de vida de uma população encerram, em si, um valor que transcende ao próprio ato de nomeação: se a Toponímia situa-se como uma crônica de um povo, gravando o presente para o conhecimento das gerações futuras, o topônimo é o instrumento dessa projeção temporal (DICK, 1990, p. 21-22).
}

Em relação à toponímia do Brasil, Dick (1990) pontua que essa é cíclica, os nomes de lugar podem se repetir de forma periódica (tem estrita relação com formação étnica da população), heterogênea e mestiça (sua formação remete ao passado e aos habitantes do lugar) em uma diversidade que não altera a unidade nacional comum.

Dick (1986, p.39 - 40) classificou os topônimos em contextos diversificados, o qual os organizou em taxionomias. Ao que se pode observar nos quadros 1 e 2, são 27 taxinomias, assim distribuídas: 11 taxes de natureza física (caracterizam o ambiente em todos os aspectos que compõem sua formação - rios, córregos, dimensões, formações topográficas, árvores, animais, etc.) e 16 taxes de natureza antropocultural (caracterizam as manifestações psíquicas, sociais e culturais do homem, no meio em que se encontra - estado de ânimo, sentimentos, nomes próprios, nomes de cidades, estados, países, títulos).

elaboração da coletânea São Luís em dados lancada em 2017. Acessado em 01/08/2020. Disponível em http://www.saoluis.ma.gov. 
Revista Ensino de Geografia (Recife) V. 4, No. 3, 2021

Quadro 1: Taxes de natureza física

\begin{tabular}{|c|c|c|}
\hline Classificação toponímica & Definição & Exemplo \\
\hline Astrotopônimo & $\begin{array}{l}\text { Topônimo referente aos nomes dos corpos } \\
\text { celestes }\end{array}$ & Saturno-ES \\
\hline Cardinotopônimo & $\begin{array}{l}\text { Topônimo referente às posições geográficas } \\
\text { em geral. }\end{array}$ & Lagoa do Sul-SC \\
\hline Cromotopônimo & Topônimo referente às cores & Rio Pardo - SP \\
\hline Dimensiotopônimo & $\begin{array}{l}\text { Topônimo referente às características do } \\
\text { acidente. }\end{array}$ & Riacho Grosso - SE \\
\hline Fitotopônimo & Topônimo referente aos nomes de vegetais & Pinheiral $-R J$ \\
\hline Geomorfotopônimo & $\begin{array}{l}\text { Topônimo referente às formas topográficas e } \\
\text { às formações litorâneas }\end{array}$ & Costa rica $-M T$ \\
\hline Hidrotopônimo & $\begin{array}{l}\text { Topônimo referente } \\
\text { hidrográficos }\end{array}$ & Foz do Riozinho - AM \\
\hline Litotopônimo & $\begin{array}{l}\text { Topônimo de índole mineral, relativos à } \\
\text { constituição do solo }\end{array}$ & Pedreiras - $M G$ \\
\hline Meteorotopônimos & $\begin{array}{l}\text { Topônimo referente aos fenômenos } \\
\text { atmosféricos }\end{array}$ & Riacho das Neves - BA \\
\hline Morfotopônimos & $\begin{array}{l}\text { Topônimo referente aos sentidos e formas } \\
\text { geométricas }\end{array}$ & Triângulo $-M T$ \\
\hline Zootopônimos & Topônimo de índole animal. & Vacaria $-R S$ \\
\hline
\end{tabular}

Fonte: Dick (1986, p.39-40)

Quadro 2: Taxes de natureza antropocultural

\begin{tabular}{|c|c|c|}
\hline Classificação toponímica & Definição & Exemplo \\
\hline $\begin{array}{l}\text { Animotopônimo (ou } \\
\text { Nootopônimo) }\end{array}$ & $\begin{array}{l}\text { Topônimo referente à vida psíquica e à cultura } \\
\text { espiritual. }\end{array}$ & Triunfo - $A C$ \\
\hline Antropotopônimo & $\begin{array}{l}\text { Topônimo referente aos nomes próprios e } \\
\text { individuais. }\end{array}$ & Fernão Velho - $A L$ \\
\hline Axiotopônimos & 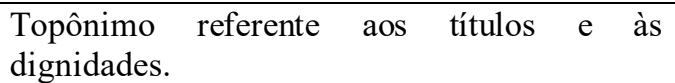 & Doutor Pedrinho - SC \\
\hline Corotopônimos & $\begin{array}{l}\text { Topônimo referente aos nomes de cidades, } \\
\text { países, regiões ou continentes. }\end{array}$ & Amazonas - BA \\
\hline Cronotopônimos & $\begin{array}{llll}\begin{array}{l}\text { Topônimo } \\
\text { cronológicas }\end{array} & \text { referente às } & \text { indicações } \\
\end{array}$ & Nova Viçosa $-B A$ \\
\hline Ecotopônimos & $\begin{array}{l}\text { Topônimo referente às habitações de modo } \\
\text { geral. }\end{array}$ & Ocauçu-SP \\
\hline Ergotopônimo & Topônimo referente aos elementos da cultura. & Relógio - PR \\
\hline Etnotopônimos & $\begin{array}{l}\text { Topônimo referente aos elementos étnicos } \\
\text { isolados. }\end{array}$ & Rio Xavante $-M T$ \\
\hline Dirrematotopônimo & $\begin{array}{l}\text { Topônimo constituído de frases ou enunciados } \\
\text { linguísticos. }\end{array}$ & Valha-me Deus-MA \\
\hline Hierotopônimo & $\begin{array}{l}\text { Topônimo referente aos nomes sagrados. } \\
\text { (Hagiotopônimo, quando há referência aos } \\
\text { santos e santas); e Mitotopônimo quando há } \\
\text { referência às entidades mitológicas). }\end{array}$ & $\begin{array}{l}\text { Cruzes - PE; São Pedro-SC } \\
\text { (hagiotopônimo) Curupira - } \\
\text { AM (Mitotopônimo) }\end{array}$ \\
\hline Historiotopônimo & $\begin{array}{l}\text { Topônimo referente aos movimentos } \\
\text { histórico-sociais e aos seus membros. }\end{array}$ & Independência $-A C$ \\
\hline Hodotopônimo & $\begin{array}{l}\text { Topônimo referente às vias de comunicação } \\
\text { rural ou urbana. }\end{array}$ & Córrego do Atalho - GO \\
\hline Numerotopônimos & Topônimo referente aos adjetivos numerais. & Duas Pontes $-R O$ \\
\hline Poliotopônimos & $\begin{array}{l}\text { Topônimo constituído pelos vocábulos aldeia, } \\
\text { vila, povoação, arraial. }\end{array}$ & Rio da Cidade - RJ \\
\hline Sociotopônimo & $\begin{array}{l}\text { Topônimo referente às atividades profissionais } \\
\text { ou a ponto de encontros }\end{array}$ & Oficina $-M G$ \\
\hline Somatopônimos & $\begin{array}{l}\text { Topônimos referentes às relações metafóricas } \\
\text { das partes do corpo humano ou animal. }\end{array}$ & Rio da Mão Esquerda - $A L$ \\
\hline
\end{tabular}

Fonte: Dick (1986, p.39-40) 
Revista Ensino de Geografia (Recife) V. 4, No. 3, 2021

As taxionomias de Dick, abrangem com perfeição a motivação do processo de nomeação. O importante neste modelo é que é todo trabalhado no ambiente brasileiro e todo estruturado em nossa língua, o que favorece a pesquisa dos topônimos. Neles a autora demonstra os tipos de estudo, o campo de pesquisa e atuação da toponímia, além de exemplos da relação entre os nomes e os locais.

Os procedimentos utilizados corresponderam no princípio à pesquisa bibliográfica e documental para fins de embasamento teórico acerca de conceitos pertinentes a Geografia e Toponímia. A pesquisa bibliográfica tomou como base autores no âmbito nacional, locais e regionais, visando a compreensão dos aspectos históricos e geográficos relativos à área de estudo. A pesquisa documental foi realizada em banco de dados literários e acadêmicos de São Luís - MA para obter informações sobre os topônimos que constituíam a área urbana, objeto de estudo.

Por meio dos dados coletados, foi possível pôr em prática a classificação taxionômica de Dick. As tabelas o a seguir representam os dados pesquisados e analisados que constam no endereço de 70 alunos matriculados no Primeiro Ano, indicando a sua classificação taxionômica e as respectivas ruas que se enquadram em tal definição.

Tabela 1: Classificação dos topônimos de natureza física

\begin{tabular}{l|c|l}
\hline CLASSIFICAÇ̃̃O & QUANTIDADE & DEFINIÇÕES \\
\hline Cardinotopônimo & 1 & Alto Mirante \\
\hline Fitotopônimo & 5 & Buriti, Cajueiro, Campo, Uva e Vidigal \\
\hline Metereotopônimo & 1 & Primavera \\
\hline Zootopônimo & 1 & Cisne \\
\hline Total & 8 & \\
\hline
\end{tabular}

Fonte: Elaborado pelo autor, 2020

Tabela 2: Classificação dos topônimos de natureza antropocultural

\begin{tabular}{l|c|l}
\hline CLASSIFICAÇÃO & QUANTIDADE & DEFINIÇÕES \\
\hline Animotopônimos & 2 & Bom Sucesso, União \\
\hline Antrotopônimoss & 11 & $\begin{array}{l}\text { Gervásio Santos, Enoc Vieira, Getúlio Vargas, Isabel Bacelar, } \\
\text { João Soeiro, Oliveira Nunes, Paulo Salomão, Sarney, Tancredo } \\
\text { Neves, Vinicius de Moraes }\end{array}$ \\
\hline Corotopônimo & 14 & $\begin{array}{l}\text { Zâmbia, Antilhas, Argélia, Bélgica, Bolívia, Filipinas, Iraque, } \\
\text { Itália, Malásia, Nicarágua, Palestina, Suriname, Tailândia, Tibet. }\end{array}$ \\
\hline Cronotopônimo & 1 & Nova \\
\hline Ergotopônimo & 1 & Igreja \\
\hline Etnotopônimo & 1 & Tain \\
\hline Hagiotopônimos & 7 & $\begin{array}{l}\text { São Benedito, São Domingos, São José, São Luís, São Pedro, São } \\
\text { Raimundo, São Sebastião. }\end{array}$ \\
\hline Historiotopônimo & 1 & Pátria \\
\hline
\end{tabular}


Revista Ensino de Geografia (Recife) V. 4, No. 3, 2021

\begin{tabular}{l|c|l}
\hline Hodotopônimos & 3 & Entroncamento, Principal, Projetada \\
\hline Numerotopônimos & 3 & $1,3,13$ \\
\hline Sociotopônimo & 1 & Bom Pastor \\
\hline Total & 45 &
\end{tabular}

Fonte: Elaborado pelo autor, 2020

O Centro de Ensino Anjo da Guarda, localizado na área urbana do município de São Luís no bairro que a nomeia foi a base para aplicação e diálogo sobre os resultados da pesquisa com os alunos do Primeiro Ano do Ensino Médio visto que a Base Nacional Comum Curricular - BNCC, documento que norteia os currículos em nível nacional, deixa aberto para as propostas regionais e estaduais, valorizarem o "mundo vivido", demonstrando ao longo do documento que este mundo vivido tem no "lugar vivido" seu ponto de partida.

Os conceitos-chaves de Geografia, entre eles o que engloba a definição de lugar, são trabalhados no Primeiro Ano desta modalidade de ensino da Educação Básica. Uma abordagem colaborativa com a pesquisa toponímica surge como forma de dar continuidade do processo de formação e refletir sobre esta temática na comunidade ampliando ainda mais os saberes científicos.

Durante a aplicação do projeto foi necessário romper a distância em tempos de pandemia com alteração no calendário escolar, e durante um tempo até mesmo com a suspensão das atividades, foram constatados inúmeros desafios no que diz respeito as condições tecnológicas e socioeconômicas dos professores e alunos, mas a retomada do Calendário Escolar ocorreu no formato remoto.

\begin{abstract}
Ensinar remotamente não é sinônimo de ensinar a distância, embora esteja diretamente relacionado ao uso de tecnologia e, nesse caso, digital. $\mathrm{O}$ ensino remoto permite o uso de plataformas já disponíveis e abertas para outros fins, que não sejam estritamente os educacionais, assim como a inserção de ferramentas auxiliares e a introdução de práticas inovadoras. A variabilidade dos recursos e das estratégias bem como das práticas é definida a partir da familiaridade e da habilidade do professor em adotar tais recursos. (GARCIA, 2020, p.8)
\end{abstract}

Apesar de constatar desafios durante esse tempo, ocorreram discursões e consultas a comunidade estudantil, avaliando o cenário de propagação e de contágio da COVID-19, a fim de definir como poderia retornar as atividades e garantir o bem mais essencial e precioso para todos: A VIDA! ${ }^{10}$

10 O Governo do Estado do Maranhão por meio do decreto No 35662 DE 16/03/2020, suspendeu por 15 dias, as aulas presenciais nas unidades de ensino da rede estadual de educação, do Instituto Estadual de Educação, Ciência e Tecnologia do Maranhão - IEMA, da Universidade Estadual do Maranhão - UEMA e da Universidade 


\section{Revista Ensino de Geografia (Recife) V. 4, No. 3, 2021}

Em face do necessário distanciamento social como medida de proteção da proliferação e disseminação da Covid-19. A pandemia moveu a todos de nossa normalidade e, temporariamente da presença física no ambiente escolar. Mas, não arrancou a possibilidade de construir, nesse novo normal, uma experiência colaborativa de ensino e de aprendizagem, com o uso de Tecnologias Digitais de Informação e Comunicação e (TDIC).

Para a retomada das aulas, implementou uma política de inclusão digital com a distribuição de chips aos estudantes do terceiro ano do ensino médio, bem como outras ações para o apoio na realização das atividades escolares, lançamentos de plataformas de formação integral para professores da rede pública com apoio pedagógico e socioemocional, webnares com alunos sobre retomada as aulas no formato remoto, escuta de profissionais da educação básica com vistas sobre o enfrentamento da pandemia e continuidade do ano letivo.

As atividades escolares retornaram após a suspensão das aulas e em formato não presencial - remotamente. As estratégias precisam ser diferentes para fim de cumprimento da integralização dos conteúdos e aplicação dos estudos sobre topônimos. As formas síncrona e assíncrona forma consideradas.

As atividades síncronas são aquelas que contam com a participação simultânea do professor e dos alunos no mesmo ambiente virtual. Na comunicação síncrona, o(a) professor(a) agenda uma aula remota, há uma interação simultânea, como chat, whatsapp ou web conferência. Então para a apresentação da pesquisa sobre os topônimos, visando oportunizar intervenções e perguntas, tempo para leitura e aprofundamento, foi utilizado além do diálogo nos grupos de whatsapp da turma outra plataforma de fácil acesso, web conferências através do Google Meet.

Com o levantamento de dados e registro em mãos das ruas que constam em seus endereços ocorreram as aulas assíncronas, aquelas em que não há simultaneidade entre professor e estudante na realização das tarefas. Os alunos foram orientados a descreverem os topônimos apresentados de acordo com a classificação toponímica de DICK (Quadro 01 e 02) com o propósito de realizar um estudo sobre a Toponímia, especificamente sobre a rua onde mora e promover uma reflexão do ensino de Geografia sobre a absorção do conceito lugar quando contextualizado com o estudo dos topônimos. Definida a atividade, os alunos realizaram observando o prazo estabelecido. O controle de qualidade deu-se com a revisão, digitação e edição dos dados pelo professor/pesquisador.

Estadual da Região Tocantina do Maranhão - UEMASUL, incluindo as instituições de ensino das redes municipais e as escolas e instituições de ensino superior da rede privada localizadas no Estado do Maranhão. 


\section{Resultados}

Os estudos trouxeram à tona e elucidaram a compreensão sobre o nome, de modo particular, os nomes das ruas, locais de vivência dos alunos que participaram da pesquisa aplicada no Centro de Ensino Anjo da Guarda, os quais foram fundamentais para compreender como os grupos sociais se organizaram no bairro e em seu entorno e articularam o ato de nomear os logradouros.

Quanto a produção do quadro de classificação dos topônimos foi analisada a participação de 76 alunos. Sendo assim, foi possível observar que todos os alunos sabiam o nome de sua rua onde moram. Porém, em relação aos motivos para a denominação destes nenhum aluno soube responder a motivação toponímica. Sobre o nome do bairro que também denomina a escola nenhum dos alunos responderam corretamente que se tratava de um sítio onde hoje é chamado de Residencial Ana Jansen, lá era o Sítio Anjo da Guarda.

Conforme evidencia-se nas informações a respeito da tabela de apresentação dos dados, dos 54 topônimos de ruas encontrados no lócus de base da pesquisa, 45 (84,9\%) são de natureza antropocultural e apenas 8 (oito), equivalente a 15,1\%, são de natureza física.

$\mathrm{Na}$ análise dos topônimos de natureza antropocultural é marcante a taxionomia dos corotopônimos que corresponde ao maior número de ocorrências com 14 (31,1\%) e antrotopônimos com 11 (24,4\%). Das nomenclaturas restantes, 20 (55,5\%), temos o maior número de ocorrências de hagiotopôniomos, 7 (15,5\%). Os demais não ultrapassam $6 \%$ cada como o caso dos hodotopônimos.

Isso deixa claro que, nomear as ruas do bairro do Anjo da Guarda não foi um ato aleatório. A escolha dos corotopônimos - topônimos referentes aos nomes de cidades, países, regiões ou continentes. - é tida por muitos moradores como uma referência ao cenário de globalização mundial o qual o estado estava sendo inserido com os Grandes Projetos das décadas de 60,70 e 80 que coincidem com o surgimento do bairro.

Os espaços públicos nomeados com os antropotopônimos - é uma prática comum na cidade de São Luís, pois é uma forma de garantir que as oligarquias mantenham impressas sua personalidade na memória coletiva da cidades por razões específicas de reprodução do poder - Rua José Sarney, homenagear personalidades da política nacional - Ruas Getúlio Vargas, Rua Tancredo Neves, política estadual e municipal - Rua Dep. Gervásio Santos e Enoc Vieira, parentes de figuras políticas - Isabel Bacelar, João Soeiro, Oliveira Nunes, Paulo Salomão e o poeta e compositor brasileiro Vinicius de Moraes. 


\section{Revista Ensino de Geografia (Recife) V. 4, No. 3, 2021}

Revelou-se que entre os topônimos de natureza física, destacam-se os fitotopônimos - topônimos referentes a nome de vegetais, com referência a elementos que compõem a paisagem natural - Rua Buriti e Cajueiro - são espécies presentes na flora da qual o bairro está localizado. A falta de topônimos que remetem a topografia, a fauna, a flora e a hidrografia da região onde a rua está inserida refletem o caráter crítico e interdisciplinar da ciência toponímica.

É importante destacar os hierotopônimos, nomes sagrados de origem religiosa que retratam a fé do povo, referências aos nomes de santos e santas (hagiotopônimos). Isso é um traço marcante no Bairro do Anjo da Guarda que se destaca pela relevância da religião católica representado na Igreja de Nossa Senhora da Penha, que começou como uma capela e hoje é uma Paróquia de arquitetura moderna, no espetáculo Paixão de Cristo que é encenado pelos moradores do bairro há 38 anos montado nas principais praças do bairro e no teatro Itapicuraiba, suspenso em 2020 devido a pandemia, que conta a história dos últimos dias de Jesus Cristo até a sua ressurreição no domingo de Páscoa. Estes topônimos foram um traço marcante na campanha colonizadora no litoral e o povoamento do interior onde batizavam com nomes santos. O próprio aparecimento do núcleo habitacional do bairro, mantendo o nome de um antigo sítio expõe e destaca para a religiosidade ali presente na crença cristã.

Ao discorrer sobre toponímia no ensino de Geografia foi possível ampliar o protagonismo e formação de sujeitos críticos e conhecedores da sua realidade no âmbito local e regional. Instigar sobre o nome da rua onde mora, dialogando com o contexto de surgimento do bairro, sua expansão urbana e o ato de denominação das ruas demonstrou ser uma oportunidade essencial para o debate e construção dos conceitos geográficos de lugar, identidade regional e território. Esta metodologia de ensino é interdisciplinar e merece ser partilhada, pois, demonstrou ser capaz de fazer uma leitura contextualizada com o cotidiano discente.

\section{Considerações finais}

A pesquisa toponímica vinculada ao ensino de Geografia promoveu estudos dos conceitos de lugar, identidade, território e elementos que envolvem os topônimos, como resgate a memória, identidade local e regional, relações de poder, aspectos físicos e patrimônio cultural das ruas que são vivenciadas pelos alunos do Primeiro Ano do Centro de Ensino Anjo da Guarda. 


\section{Revista Ensino de Geografia (Recife) V. 4, No. 3, 2021}

O formato de aplicação da proposta de estudo do lugar através da perspectiva dos topônimos mediado por tecnologia, manteve as condições de distanciamento entre professor e aluno. O ensino remoto demonstrou que é possível, com acessibilidade e apoiado nas tecnologias digitais, promover o engajamento do aluno no processo ensino-aprendizagem. A prática demonstrou ser inovadora e envolvente fortalecendo a condição de aluno/pesquisador desde os anos iniciais do Ensino Médio, permitiu ainda analisar as condições reais que os alunos possuem e desenvolver um ensino ativo por parte do professor e protagonismo dos alunos frente as necessidades atuais.

Enfim, é possível entender que cada topônimo é capaz de revelar elementos singulares referentes a localidade em que o aluno está inserido. A nomenclatura dos espaços retrata realidades diversas, capaz de refletir saberes, culturas, identidades, crenças e ideologias. O estudo dos nomes de lugares permite ao Ensino de Geografia uma aproximação maior entre o conteúdo formal e a prática educativa.

A formação identitária de um povo parte também do ato de nomear os espaços e os meios sociais, é uma forma de evidenciar os pensamentos, as crenças, as condutas e imprimir as identidades de cada ser, dentro de um contexto social, cultural e político. Com as ruas identificadas na pesquisa não foi diferente. Os primeiros a povoarem esse espaço buscaram se valer do contexto histórico, domínio político, das relações de poder e posse, para nomear e tecer as redes de identificações.

Dessa forma, a partir das discussões apresentadas neste artigo, acredita-se que os estudos toponímicos desenvolvidos na pesquisa e aplicados na escola junto aos discentes envolvidos, pode-se conhecer de perto um pouco de sua realidade e a produção de senso crítico atrelado a necessidade de reprodução social, o que, com certeza, é de grande relevância para a qualidade do processo de ensino-aprendizagem.

\section{Referências}

ABREU, Maurício de Almeida. Sobre a memória das cidades. Revista da faculdade de Letras - Geografia, I série, vol. XIV, Porto, 1998, PP. 77-97.

ANDRADE, K. S. O lugar nos estudos toponímicos: reflexões. Revista de Estudos da Linguagem, Belo Horizonte, v.25, n.2, p. 585-607, 2017. Disponível em: http://www.periodicos.letras.ufmg.br/index.php/relin/article/view/9547. Acesso em 10 mar. 2020.

BARBOSA, J. R. A. Formação territorial e oligarquias estaduais: notas sobre o uso desigual do território norte-rio-grandense. Revista Interface. Porto Nacional, n.12, p.34-54, 


\section{Revista Ensino de Geografia (Recife) V. 4, No. 3, 2021}

dez. 2016. Disponível em: < https://sistemas.uft.edu.br/periodicos/index.php/interface/index>. Acesso em: 25 jun. 2020.

BRASIL, Ministério da Educação (2018). Base Nacional Comum Curricular. Recuperado de http://basenacionalcomum.mec.gov.br/images/BNCC_EI_EF_110518_versaofinal_site.pdf

BUZAR, Benedito. O vitorinismo: lutas políticas no Maranhão de 1945 a 1965. São Luís: Lithograf, 1998.

CALLAI, H. C. Estudar o lugar para compreender o mundo. In: CASTROGIOVANNI, A. C. (Org.). Ensino de geografia: práticas e textualizações no cotidiano. Porto Alegre: Mediação, p. 71-114, 2000.

CARLOS, Ana Fani Alessandri. O lugar no/do mundo. São Paulo: FFLCH, 2007, 85p.

CASTRO, Iná Elias de. O mito da necessidade: discurso e prática do regionalismo nordestino. São Paulo: Editora Bertrand do Brasil, 1992.

CASTRO, Mária Célia Dias de. Atlas toponímico do estado do Maranhão: uma proposta de análise da macrotoponímia. Caderno Seminal Digital, n. 28, p. 110-147, jan. 2017. Disponível

em: $<$ https://www.epublicacoes.uerj.br/index.php/cadernoseminal/article/view/28381 $>$ Acesso em: 20 de 08.2020 .

CLAVAL, Paul. A Geografia Cultural. 3.ed. Florianópolis: UFSC, 2007.

COSTA, Edlucy e ZAGO, Fortunato. Dinâmica histórica e Urbana de São Luís. São Luís: Instituto da Cidade, 2008.

COSTA, Marcelo Lima. Das chamas nasce um Anjo: a formação do bairro Anjo da Guarda, em São Luís do Maranhão no contexto do milagre econômico (1968-1980). VI Congresso Internacional de História: Anais eletrônicos <www.2018.congressohistoriajatai.org>. Jataí. Universidade Federal de Goiás/Campus Jataí, 2018.

CURVELO-MATOS, Heloísa Reis. Análise toponímica de 81 nomes de bairros de São Luís/MA. 347f. Tese (doutorado). UFC, Fortaleza, 2014.

D'ABBEVILLE, Claude. História da missão dos padres capuchinhos na Ilha do Maranhão e terras circunvizinhas. Belo Horizonte: Ed. Itatiaia, 1975.

DICK, Maria Vicentina de Paula do Amaral. Toponímia e antroponímia no Brasil. Coletânea de estudos. São Paulo - SP: Impresso pelo Serviço de Artes Gráficas da Faculdade de Filosofia, Letras e Ciências Humanas / USP, 1986. 1990, 387p.

. A motivação toponímica e a realidade brasileira. São Paulo, Arquivo do Estado,

DUTRA, Laércio da Silva. Mercado público: função, forma e transformação do espaço urbano na região Itaqui-Bacanga, São Luís (MA). 250f. Dissertação (Mestrado em Geografia). UEMA, São Luís, 2017. 
ESPÍRITO SANTO, José Marcelo (org.). São Luís: uma leitura da cidade. São Luís: Instituto da Cidade, 2006.

GARCIA, Tânia Cristina Meira et al. Ensino remoto emergencial: proposta de design para elaboração das aulas. SEDIS/UFRN, Natal, 2020. 18p. Acessível em: https://educapes.capes.gov.br/handle/capes/571153

GUILHON, Maria, V. M. Sarneísmo no Maranhão: os primórdios de uma oligarquia. Revista Políticas Públicas, São Luís, v. 11, n. 1, p. 125-148, jan/jun. 2007 HAESBAERT, R. Identidades territoriais. In: ROSENDAHL, Z.; CORREAA, R. L. (Org.) Manifestações da cultura no espaço. Rio de Janeiro: Eduerj, 1999. p. 169-190.

. O mito da desterritorialização: do "fim dos territórios" à multiterritorialidade. Rio de Janeiro: Bertrand Brasil, 2004.

INSTITUTO BRASILEIRO DE GEOGRAFIA E ESTATÍSTICA - IBGE. Censo demográfico, 2010. Disponível em: $<$ https://cidades.ibge.gov.br/brasil/ma/saoluis/panorama>. Acesso em 05 de 08. 2020.

MARANHÃO. DECRETO nº 35662 de 16 de mar. 2020

MELO, Magnólia Sousa Bandeira. Índice toponímico de Centro histórico de São Luís. São Luís: EDUFMA, 1990, 121p.

MORAIS, Antônio Carlos Robert. Bases da formação territorial do Brasil: O território colonial brasileiro no "longo" século XVI. São Paulo: Ed. Hucitec, 2000.

MOTA, Antonia da silva e MANTOVANI, José Dervil. São Luis do Maranhão no Século XVIII: a Construção do Espaço Público sob a Lei das Semarias. São Luís: Func, 1988.

PINTO, G. J. Do sonho à realidade: Córrego Fundo - MG, fragmentação territorial e criação de municípios de pequeno porte. 248f. Dissertação (Mestrado em Geografia). IG-UFU, Uberlândia, 2003.

RAMOS, Ricardo Tupiniquim. Toponímia dos municípios da Bahia: descrição, história e mudanças. Tese de Doutorado. Salvador: UFBA, 2006.

SANTOS, Herbert de Jesus. Um Terço de Memória: Entre Anjo da Guarda e Capela de Onça, e os Heróis do Boi de Ouro. São Luís: Lithograf, 2012.

SANTOS, Milton. A natureza do espaço. São Paulo: Hucitec, 1996.

SÃO LUÍS, LEI n 2.151 DE 04 de fev. 1975.

SEPLAN, Secretaria Municipal de Planejamento. Leitura urbana - São Luis. São Luís, 2014 
Revista Ensino de Geografia (Recife) V. 4, No. 3, 2021

SOUSA, J. H. P. MARCOLINO, R. R. S. A representação da identidade regional do Nordeste na telenovela. NAMID/UFPB, ano XII, n. 06. Junho/2016. Disponível em: $<$ https://periodicos.ufpb.br/ojs2/index.php/tematica> Acesso em: 10 de abr. 2020.

TUAN, Yi-Fu. Espaço e Lugar: a perspectiva da experiência. São Paulo: DIFEL, 1983.

VIDAL DE LA BLACHE, Paul. Sobre o espírito geográfico. Revista Política e Literária. $\mathrm{n}^{\circ} 18$, ano 52. Paris: Gabinetes da Revista Política e Literária e da Revista Científica, p. 556560,1914 .

VIEIRA FILHO, Domingos. Breve história das ruas e praças de São Luís. São Luís: Olímpica, 1971. 